INDIA

\section{New Chief for INSA}

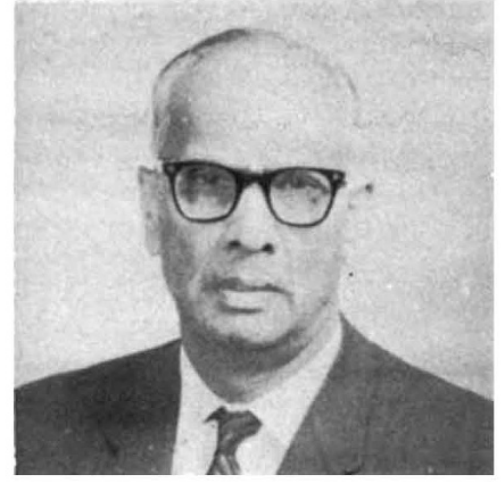

DR B. R. Seshachar, professor of biology and director of the Centre for Advanced Research in Cell Biology and Endocrinology at the University of Delhi, has been appointed President of the Indian National Science Academy. Well known for his work on the cytology and cell biology of animals, particularly of protozoa, Dr Seshachar is chairman of the National Committee for Biological Science in India and of the Indian National Committee for the International Biological Programme. His chief field of study has been the organization of chromosomes in the macronucleus.

The Indian National Science Academy is the premier scientific society in India, discharging functions similar to those of the Royal Society, but also giving grants for basic research in India. It has 354 Fellows and about 38 honorary Fellows. Dr Seshachar takes over from Dr Atma Ram, Director General of the Council for Scientific and Industrial Research.

\section{SOVIET UNIVERSITIES}

\section{Broad Expansion}

from our Soviet Correspondent

THE training of scientists in the Soviet Union may be too narrow. That is one conclusion to be drawn from a recent article by the Rector of Odessa University, A. Bogatskii, published in Pravda (March 2, 1971) in connexion with the directives of the new five year plan.

The new plan calls for "necessary measures" to be taken to train "highly qualified specialists and workers". The majority of these, under the present educational system of the Soviet Union, will be trained in technical colleges and institutes of higher education. Professor
Bogatskii says, however, that the training offered by these institutions is too rapid and too limited. It is well known, he suggests, that there are considerable differences in the level of knowledge of the theoretical principles of their subject between those graduating from technical colleges and those from universities. In the chemical technology faculties of polytechnics, for example, students spend only about half the time on the fundamental chemical disciplines that they do in universities. Consequently, they can take in much less scientific information. Technical colleges, he claims, are more suitable for the training of specialists in "narrow, concrete, engineering subjects" for which the time allowed by the academic planners is quite sufficient. He urges, however, the further expansion of universities as the training ground of specialists of the future, for here the student will have a chance to acquire a profound knowledge not only of his own special subject but also of neighbouring disciplines.

University expansion, of course, has been going forward rapidly in the Soviet Union during the last five years. Professor Bogatskii's own University of Odessa, for example, now possesses nine faculties, 63 departments, several scientific research institutes, including an astronomical observatory, a botanical garden, palaeontological and zoological museums, a computer centre and many similar facilities. The academic and research staff now number more than 350 , and there are 11,500 students. The high cost of expansion is, to a certain extent, offset by the earnings of the research institutes which undertake contract work for industry. (In 1970, says Bogatskii, 1.1 million rubles was earned from this source.) Many of the applied problems thus studied involve a number of departments and faculties, and are undertaken in conjunction with the research institutes of the All-Union and Ukrainian Academies of Sciences.

The close cooperation of academic institutions and industry is a basic tenet of Soviet educational planning. An industryorientated approach to science has been particularly emphasized in the technical colleges and Institutes of Higher Education. While the importance of this close link is still paid some lip service, it is interesting to note that the current tenor of educational expansion seems to be towards universities in which students receive a more broadly based education.

\section{AVIATION}

\section{Light Under a Bushel}

THE new chairman of the relatively little known but very active Aeronautical Research Council is to be Professor Paul Owen, who holds the Zaharoff chair of aviation at Imperial
College, London. Professor Owen succeeds Professor A. D. Young, whose three-year term of office expires at the end of March.

The Aeronautical Research Council, set up in 1909 with the title of Advisory Committee for Aeronautics, has evolved into a body to which the Minister of Aviation Supply can turn for independent advice on all aspects of aeronautical research. Two of the reasons for its absence from the public gaze are that it has no executive responsibilities and does not disseminate funds.

Its independence is one of its chief assets, and although there are ten official members of the twenty-two strong council, the other twelve are appointed by the Minister from universities, the aircraft industry, government establishments and aircraft operators. The council itself, however, selects the 300 to 400 members of the twenty or so standing committees, special committees and subcommittees which have special responsibility for matters ranging from air traffic control to hypersonic flight.

The standing committee on materials and structure has, of course, proffered advice to the minister on carbon fibre research and development from time to time, and when the topic comes up for discussion by the council next month it should be in an excellent position to make far-reaching recommendations for a future which may well not see any contribution from Rolls-Royce.

\section{OIL EXPLORATION}

\section{The UK Economic Buit}

THE recent publicity over the search for oil now gathering momentum in Britain must have come as a surprise to anyone familiar with conventional geological ideas about the underlying structure of the country. There is certainly no evidence that giant fields like those of Alaska and the Middle East are hidden beneath the UK, but even if small pockets of oil were found trapped in faults, fractures and small anticlines, they could be very easily exploited. This is the economic bait that has attracted Texan and Canadian oil companies away from their more usual environments.

Although very successful abroad (or, perhaps, because of this success) British Petroleum, which has owned concessions on large areas of land in Britain for many years, has never carried out a full scale search for oil at home. An obvious parallel can be drawn with the situation in Holland, where a reasonably large oilfield lay undiscovered for decades while Shell pursued a successful policy of overseas exploration. As in Holland, parts of Britain close to the 